\title{
PROJECT SPOTLIGHT
}

Lower Sesan 2 Hydropower Dam, Cambodia

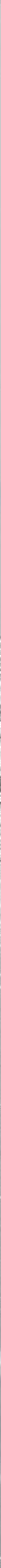




\title{
Under the Water \\ Cambodian Artist Sreymao Sao on the Lived Experience of Hydropower Dams
}

\author{
Soksophea SUONG, Sango MAHANTY, \\ and Sarah MILNE
}

n this article, we continue to explore how art can 'unflatten' our understanding of mega-infrastructure like the Lower Sesan 2 Dam

(see Milne, Mahanty, and Cristofoletti's essay in this issue). We focus on the remarkable work of Cambodian artist Sreymao Sao, who explores the lived experiences of communities displaced by the Lower Sesan 2 Dam-some 5,000 indigenous and ethnic-minority people from four villages (Mahanty 2021)-as well as those living upstream and downstream.

Sreymao Sao's work-as seen in her exhibition 'Under the Water', a collaboration with Sa Sa Art Projects, shown at the MIRAGE Contemporary Art Space in Siem Reap, Cambodia, from 11 January to 11 February 2019-explores villagers' changing experience of their rivers, lands, and lives. The title refers both to the villages submerged by the Lower Sesan 2 Dam and to downstream villages along the Mekong River who are geographically 'under' this and other dams.

The work resonates with what is now termed 'socially engaged art', which is a rising feature of art this century (Coombs 2021). It involves an artistic practice that engages with social contexts through collaborative activities and critical inquiries, stemming from a desire to make a difference, and to address pressing issues like climate change and displacement.

Sreymao's inspiration for this exhibition came from her previous work with communities along the Mekong River. After graduating in 2006 from Phare, a school for the creative arts in Battambang, Sreymao worked with various nongovernmental organisations on visual arts projects that aimed to explore environmental and social change. This included a community arts project in 2008 in Kratie and Stung Treng provinces, which took her to Koh Phdao-a village on an island in the Mekong River. There, she learned about the power of community arts and developed deep relationships with local families.

When she returned a decade later, Sreymao observed disturbing transformations in Koh Phdao, where local villagers were contending with diminished water flows and reduced fish stocks. She also witnessed villagers' acute uncertainty about the proposed Sambor Dam, which the government placed on hold in 2020 due to ongoing protests and widespread concerns about its impacts. 
In our interview, Sreymao reflects on her exhibition and, more specifically, four of her works. She contrasts the violent disruption that dams impose on flooded villages, through the case of Srae Kor on the Sesan River, with the plight of downstream communities such as Koh Phdao, where change is more incremental. Sreymao's wax sculptures and photographic images overlaid with drawings offer a haunting and emotional archaeology of the lived experience of dams across the riverscape.

Soksophea: Can you tell us how this exhibition came about?

Sreymao: In 2018, my friend and I took a motorbike trip to Koh Phdao, a place I remembered from 2008 as one of the most beautiful I had ever seen. As we drove up, a group of children were playing volleyball in a dusty and smoky field. I was stunned. This was not the village I remembered. There were far fewer people, and many houses were locked up and seemed abandoned. I felt sad when I saw a man sitting alone, silently, in front of his neglected house, which I remembered as once being beautiful, organised, and tidy. He was a 'model farmer' when I knew him before, but his life had been transformed by a visual impairment. A couple who used to cook me meals when I worked there in 2008 had passed away. I felt heartbroken by the changes I observed; some of this may have been due to the dry season, but not all of it.

When I worked in Koh Phdao in 2008, the issue of hydropower dams-both upstream and downstream-was being talked about and was already seen as a problem. Yet, the village was beautiful and people seemed content with their lives. I remember their daily routines. Villagers woke up around $5 \mathrm{am}$ and, as the day progressed, the village became noisier. There were mobile street vendors on bicycles who sold vegetables, meat, and other goods in the village, while other vendors came along the river, calling out to villagers to buy their products. Children prepared for school. I heard cowbells at dawn and, after some time, I could even recognise which cowbells belonged to which family in the village. I could guess that this uncle was passing the house or that person was coming because of the specific sound of their cowbells. The pagoda's bell in the freshness of the morning breeze and mist is the other sound I recall.

In 2018, it was so different. The soil was dried and cracked. The dirt road was dusty when it used to be moist. The whole village was quiet. I learned that many people had migrated, and I believe this was because they could not find the fish they used to rely on before-a result of the upstream Lower Sesan 2 Dam.

Witnessing all of this, we decided to go to Stung Treng to explore the source of the changes. Even though communities were heavily impacted around the dam site, the changes in Kratie deeply affected me at an emotional level. I started thinking of how to share these stories about dam impacts. 
Sreymao: We had to be careful because villagers resisting the dam were accused of siding with the opposition party [the Cambodia National Rescue Party (CNRP), which gained more than 44 per cent of the vote in the 2013 national election and was dissolved on order of the Cambodian Supreme Court in 2017]. There were two parts of Srae Kor that were forced to resettle: Srae Kor 1 and Srae Kor 2. When I thought about people leaving their village in Srae Kor, compared with those leaving Koh Phdao, I felt there was a difference. In Koh Phdao, they had to leave for survival, and it was people's own decision to leave-nobody forced them. But in Srae Kor 1 and Srae Kor 2, people were forced to leave against their wishes-even though they still could sometimes sneak back to their old village that had been flooded. I felt very sorry for them. I especially felt sad that they needed to leave their burial sites and many other things behind. I was sad that outsiders could not see how important it was to the villagers to take care of those burial sites, where their ancestors were buried.

At the new resettlement village, these indigenous villagers were living just like Khmer people. The living cost was high compared with their old village because they needed to buy all their supplies from the market, whereas in the old village they could feed themselves from the river and the forest without cash. Even the house designs and construction processes in the resettlement village were different from their former traditional housing.

Soksophea: Sreymao, let's turn now to some selected pieces from your exhibition, starting with this first image (see Figure 1), which represents Koh Phdao. Can you tell us a bit about what you were showing in this work?

Sreymao: This image shows the past, the present, and the future coming together in one place. The elders represent the past that is left behind in the village, as they silently watch their children leave. Their leaving the village is the present reality. But what about the future of the young children in the photo? Will they eventually need to leave their hometown, too?

The elders are left behind to take care of the village and young children. But ultimately, those young children could become like their parents, sisters, brothers, and friends who are leaving on the boat. Their future is uncertain because people cannot currently survive in the village. I wanted the audience to understand this and to reflect on what they can contribute to improve this situation. 


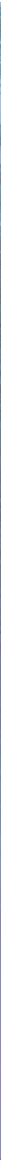

Soksophea: What about these other two images representing Srae Kor (see Figures 2 and 3)?

Sreymao: The first image (Figure 2) represents resettlement from Srae Kor. Villagers here were forced to move to a new place and many were unwilling. I used red here to represent their bloodline, to show that they not only move their physical house, but they are also uprooting themselves from their ancestors, their memories, and their childhoods; this is an emotional loss as well as a physical one. It represents everything that they wanted to take and hold close during their unwilling resettlement.

The next image (Figure 3) is of the resettlement village for people from Srae Kor, where villagers found that their lives and livelihoods were completely different from their old village. Their spirits and souls were unwell, but this was hard for them to describe and speak about. The sketch in this image represents their loss. They said that at the old village, they could easily go fishing for meals and did not need cash to survive. In the new place, they could only survive with 


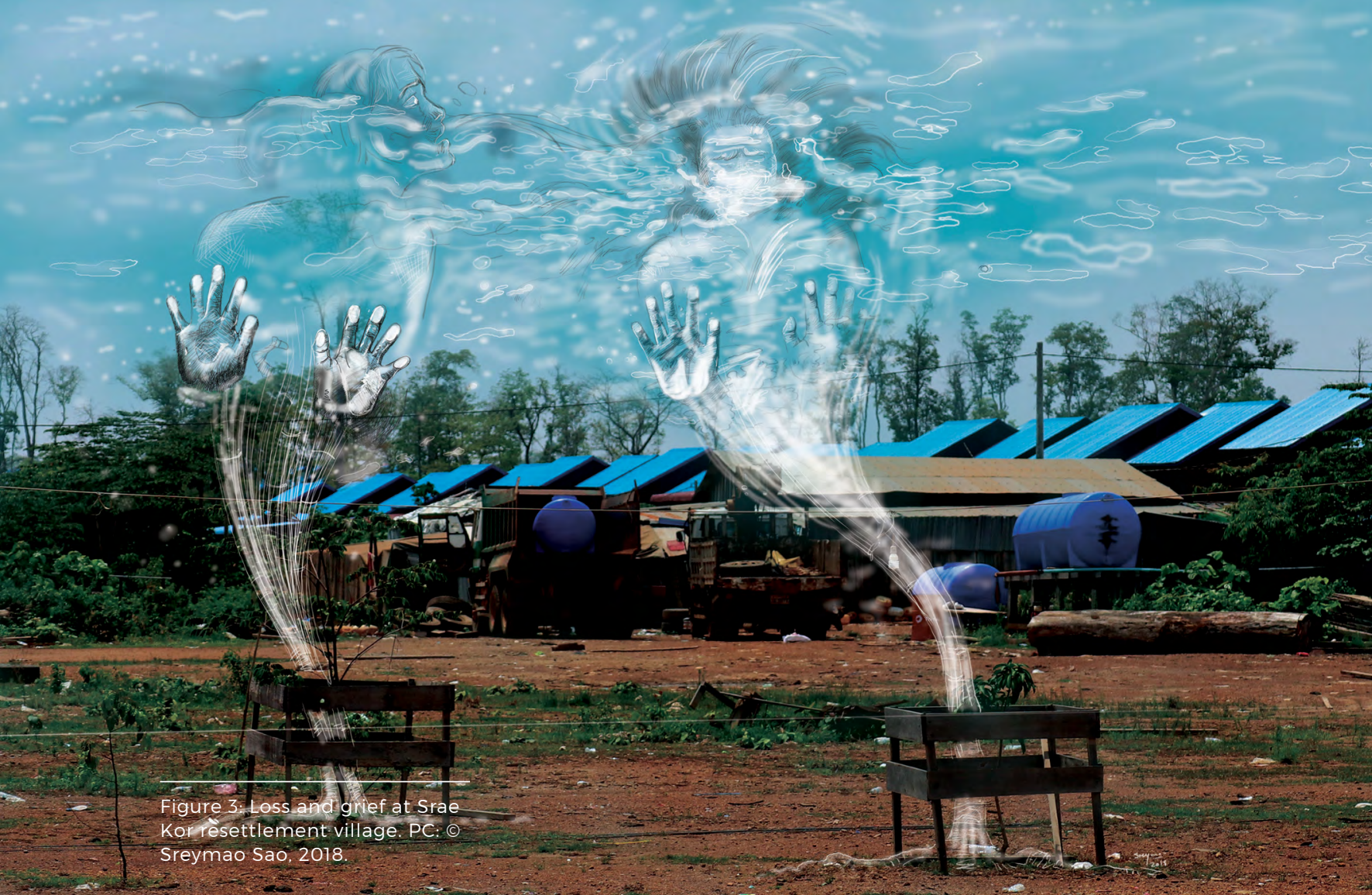

cash, and the cost of living was very high. Everything they needed had to be bought from the market. Some families said their improved access to main roads meant their children were getting into trouble. Some had accidents from riding too fast on their motorcycles, and there was a problem with drugs and substance abuse. Their spirits and souls were not healthy after leaving their old riverbank village.

Soksophea: Your images give the sense of the past living on through the present, as though ghosts of the village remain, even while the original village is underwater. Were you thinking of ghosts in this work?

Sreymao: Well, the images are not literally ghosts. They represent what has been lost and show that only memories remain. They speak to questions about the past, present, and future. I want people to reflect on whether the benefits of these dams are worth the costs. That was what motivated me to create 'Under the Water'. 
Soksophea: Can you tell us about your wax sculpture of Srae Kor, which was a centrepiece of the exhibition (see Figure 4)?

Sreymao: I created the village from wax and installed it on a mirror. The mirror represented the water and the submerging of the affected villages. Later, when I burned this wax village, the fire was like the electricity from the dam, generated at the expense of these villagers. The melted wax was like the flooding caused by the dam.

Amazingly, when I burned the wax village at the end of my exhibition, I hadn't predicted that the fire and the heat would make the mirror underneath the village crack. The sound of the cracking mirror was a very chaotic and violent moment. It was like a flashback. I thought back to what happened in those submerged villages.

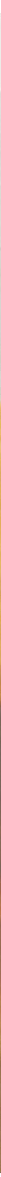


The very painful and violent process of resettlement for these villagers was hard for me or other outsiders to grasp fully. There are many things that we cannot feel and understand by just looking with our eyes, or through words. It can be hard to walk in these villagers' shoes if these events have not directly happened to us.

But when I had to burn my beloved artwork and I heard the mirror crack, it gave me a small sense of their suffering and pain. It also reminded me of the collapse of the Xe Pian-Xe Namnoy Dam in Laos that happened around that time [on this, see Inclusive Development International and International Rivers 2020].

Sango Mahanty and Sarah Milne would like to acknowledge field support by Dr Sopheak Chann, provided to Thomas Cristofoletti in March 2020 around the Lower Sesan 2 Dam. The photo essay and the interview with Sao Sreymao were supported by The Australian National University (College of Asia and the Pacific APIP fund) and the Australian Research Council (DP180101495). Views expressed in this article do not reflect the views of the Australian Research Council.

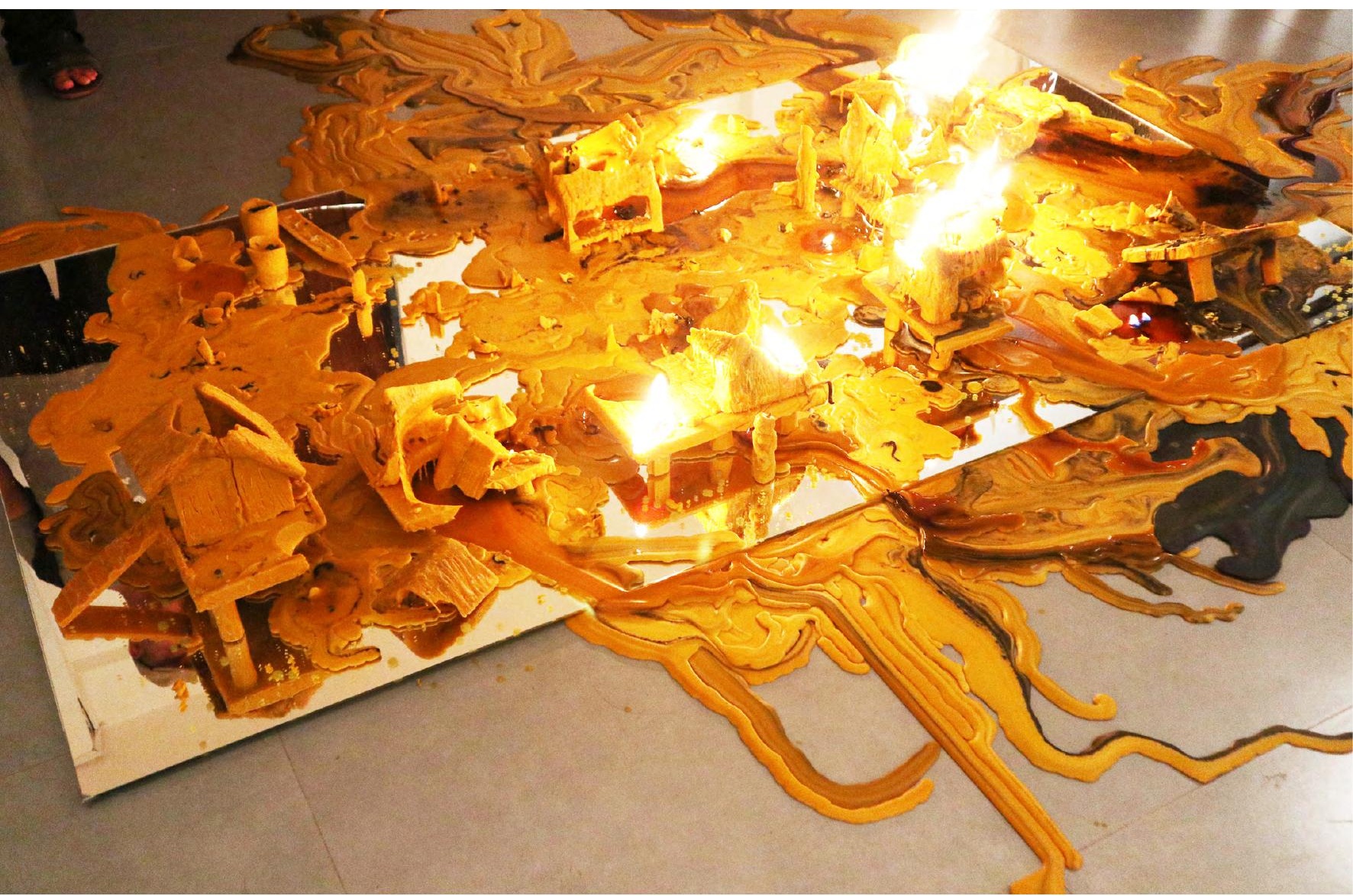


This text is taken from Made in China Journal: Volume 6, Issue 2, 2021, edited by Ivan Franceschini and Nicholas Loubere, published 2021 by ANU Press, The Australian National University, Canberra, Australia.

doi.org/10.22459/MIC.06.02.2021.30 